ПОРІВНЯЛЬНИЙ АНАЛІЗ ВИНИКНЕННЯ ТА ФУНКЦІОНУВАННЯ

ПРИЙОМНОÏ СІМ'Ї ТА ІНШИХ ФОРМ ВЛАШТУВАННЯ ДІТЕЙ, ПОЗБАВЛЕНИХ БАТЬКІВСЬКОГО ПІКЛУВАННЯ, У КРАЇНАХ ЄВРОПЕЙСЬКОГО СОЮЗУ Й УКРАЇНІ

\title{
COMPARATIVE ANALYSIS OF THE ORIGIN AND FUNCTIONING OF A FOSTER FAMILY AND OTHER FORMS OF ARRANGEMENT OF CHILDREN DEPRIVED OF PARENTAL HERITAGEIN EUROPEAN COUNTRIES AND UKRAINE
}

Однією з найважливіших міждисциплінарних $i$ загальносвітових наукових проблем залишається сирітство. У статmі проаналізовано сучасні дослідження, спрямовані на аналіз суті даного соціального явища в умовах визнання пріоритету прав та інтересів дитини, визначено суперечність між загальновизнаним у світі ставленням до дитини як самоцінності і нездатністю значної кількості батьків забезпечувати реалізацію даної цінності. Визначено, що дослідження здійснюються з метою виявлення соціальних умов і причин, за яких діти залишаються без піклування батьків, зокрема і в ситуаціях сприятливого соціально-економічного розвитку суспільства. здійснено порівняльний аналіз виникнення та фуункціонування прийомної сім'ї й інших форм влаштування дітей, позбавлених батьківського піклування, у країнах Європейського Союзу й Україні. Викладаються теоретичні основи дослідження - роботи вчених, які досліджували історію розвитку та діяльності прийомних сімей у країнах Європи та Сходу. Автором проведено аналіз щодо функціонування дитячих містечок СОС, малих групових будинків та прийомних сімей в Україні. Основна увага приділяється внутрішнім та зовнішнім проблемам організації діяльності замісного батьківства, як-от відсутність належного фрінансування, недосконалість законодавчої бази та необхідність удосконалення соціального супроводу у психологічному аспекті, співпраці з іншими структурами, неадекватне юридичне та податкове програмне забезпечення тощо. $У$ статті зроблено висновок про необхідність наукового та практичного співробітництва в галузі вирішення проблем дітей, які залишилися без піклування батьків, актуалізації форм виховання, які сприяють повноцінній соціалізації дитини, спілкуванню з біологічними батьками. Оптимальною фрормою влаштування дітей-сиріт і дітей, позбавлених батьківського піклування, визнано малий груповий будинок.

Ключові слова: прийомна сім'я, замісне батьківство, діти-сироти, малий груповий будинок.
Orphan hood remains one of the most important interdisciplinary and global scientific problems. The article analyzes modern research aimed at analyzing the essence of this social phenomenon in terms of recognizing the priority of the rights and interests of the child and identifies contradictions between the world-wide attitude to the child as self-worth and the inability of many parents to ensure the realization of this value. conditions and reasons for which children are left without parental care, including in situations of favorable socio-economic development of society. A comparative analysis of the origin and functioning of the foster family and other forms of placement of children deprived of parental care in the European Union and Ukraine. The theoretical foundations of the study are presented - the work of scientists who have studied the history of development and activities of foster families in Europe and the East. The author analyzes the functioning of SOS children's towns, small group homes and foster families in Ukraine. The main attention is paid to the internal and external problems of the organization of substitute parenting, including the lack of adequate funding, the imperfection of the legal framework and the need to improve social support in the psychological aspect. cooperation with other structures, inadequate legal and tax software, etc. The article concludes on the need for scientific and practical cooperation in solving the problems of children left without parental care, updating forms of education that contribute to the full socialization of the child and promote communication with biological parents. A small group house is considered to be the optimal form of placement for orphans and children deprived of parental care.

The article concludes that orphan hood is a common international problem. The current international situation is characterized by the priority of state and public forms of education of orphans and children deprived of parental care. Today, small group houses are a universal form of such education. Problems that arise in the process of re-socialization of the child can be solved with professionally organized psychological support Key words: foster family, surrogate parenthood, orphans, small group house. наук України

Сирітство залишається однією 3 найважливіших міждисциплінарних і загальносвітових наукових проблем. Сучасні дослідження, спрямовані на аналіз суті даного соціального явища в умовах визнання пріоритету прав та інтересів дитини, визначають суперечність між загальновизнаним у світі ставленням до дитини як самоцінності та нездатністю значної кількості батьків забезпечувати реалізацію даної цінності. Соціальні дослідження здійснюються $з$ метою виявлення соціальних умов і причин, за яких діти залишаються без піклування батьків, зокрема і в ситуаціях сприятливого соціально-економічного розвитку суспільства. Соціально-педагогічні джерела визначають наслідки виховання дітей поза сім'єю, вказують на глобальні деформації сутнісних основ особистості, її «якісно інший характер» розвитку. Практика реалізації виробленої на основі наукових підходів соціальної 
політики та соціально-педагогічної підтримки сиріт показує, що навіть незначні успіхи стикаються з організаційними перешкодами. Усе вищезазначене потребує об'єднання зусиль міжнародної спільноти щодо знаходження найбільш ефективних засобів і способів допомоги дітям-сиротам і дітям, які позбавлені батьківського піклування.

Підставою для загальновизнаних наукових і практичних відкриттів виступають гуманістичні ідеї, затверджені в Конвенції ООН про права дитини. Більшість країн світу, які ратифікувавли Конвенцію, погодилися, що невід'ємним правом дитини виступає ії право жити і виховуватися в сім'ї. Саме сім'я визнається світовим співтовариством природним і найбільш сприятливим середовищем захисту, виховання і розвитку дитини.

У разі порушення нормального середовища біологічної сім'ї дитина має право на захист у замісній сім'ї.

Метою нашого теоретичного дослідження $€$ здійснення порівняльного аналізу виникнення та функціонування прийомної сім'ї й інших форм влаштування дітей, позбавлених батьківського піклування, у країнах Європейського Союзу (далі - ЄC) та Україні.

Аналіз міжнародного досвіду дозволяє виявити різноманітність наукових концепцій і практичних форм створення замісних родин. Перехід від дитячих будинків до виховання в родині - найважливіша тенденція у світі. у більшості країн в останні двадцять років спостерігається єдина тенденція - відмова від великих дитячих установ і підтримка дітей в їхньому природному (сімейне) середовищі життєдіяльності.

У таких країнах, як Румунія, Угорщина, згідно з ухваленими в них законами щодо захисту прав дітей, умови перебування в будь-якій державній установі мають бути максимально наближеними до сімейних, кількість дітей не повинна перебільшувати тридцяти. 3 метою реалізації цих законодавчих аспектів уряд Угорщини виділяє значні кошти з державного бюджету країни. Практично в усіх постсоціалістичних країнах вищезазначені зміни викликають незадоволення в керівництва інтернатних закладів, але цей процес відбувається активно, незважаючи на опір традиційної системи виховання й утримання дітей, позбавлених батьківського піклування.

У країнах Євросоюзу й у Великобританії не залишилося дитячих будинків у традиційному розумінні. Діти, які зазнали важких психологічних травм і потребують тимчасового або тривалого відокремлення від родини, мають можливість перебувати в закладах на кшталт «групових будинків». Зупинимося на аналізі англійського законодавства, що передбачає правові підстави влаштування дітей до при- йомної сім'ї (Закон про дітей (The Children Act) 1989 р. В основу цього Закону покладено такі принципи:

- тільки рідна сім'я може надати дитині можливість для максимально повного розвитку і для забезпечення її добробуту;

- визнання безумовного пріоритету у збереженні батьківських прав / батьківської відповідальності в біологічних батьків. Батькам забезпечуються умови для збереження ними батьківської відповідальності;

- державні органи, батьки замісної сім'ї й інші особи, які забезпечують утримання дитини за межами кровної родини, зобов'язані, згідно із Законом, сприяти контактам дитини з її кровними батьками або родичами;

- державні органи зобов'язані прагнути працювати у співпраці з біологічними батьками, встановлювати цю співпрацю;

- біологічні батьки мають право брати участь у процесі ухвалення рішення про заходи допомоги дитині, оскільки так партнерство є ефективним способом домогтися прогресу в розвитку дитини в період її утримання поза домом;

- пріоритетний характер має влаштування дитини в сім'ї родичів або знайомих; якщо це неможливо, її поміщують у сім'ю, що «заміщує кровну»;

- під час утримання дитини в замісній сім'ї повинні вживатися активні заходи щодо повернення дитини в сім'ю;

- головним обов'язком усіх органів, що надають допомогу дитині та її сім'ї, $€$ індивідуальне планування заходів, що сприяють успішній соціалізації дитини;

- думка дитини є вагомим аргументом під час вирішення всього комплексу питань [2, с. 35-37].

Унаслідок тривалих психотравмувальних обставин і асоціальної життєдіяльності батьків корекція поведінки дітей-сиріт та дітей, позбавлених батьківського піклування, вимагає інтенсивного терапевтичного втручання. Ефективність такого втручання можлива за умови координації роботи мультидисциплінарної команди професіоналів на базі групового будинку. Після направлення дитини до групового будинку члени команди (до складу якої можуть входити психіатр, соціальний працівник, учитель, педіатр, дитячий працівник, психотерапевт, юрист, інколи - священик і батьки) проводять первинне оцінювання проблем та потреб дитини, на підставі якого складається план соціального супроводу кожної дитини. Орієнтовний термін реалізації плану - три місяці. Після закінчення визначеного терміну команда оцінює зміни та результати супроводу, визначає майбутні перспективи діяльності.

Історичний розвиток системи піклування про дітей Швеції має два етапи: перший (40- 
80-ті pp. XX ст.) - закриття дитячих будинків; другий (90-ті рр. XX ст.) - перехід до сімейних форм виховання. Роботу щодо закриття дитячих будинків проводив заклад «Барнбюн Ско» (Стокгольм), який протягом багатьох десятиліть $€$ ідеологічним центром розроблення системи соціальної турботи про дітей Швеції, інших скандинавських країн. Стратегія полягала в тому, що у процесі переходу до сімейних форм виховання та включення до них дітей, позбавлених батьківського піклування, пріоритетність було віддано дитині та прийомній сім'ї, але біологічні батьки теж були залучені до перебігу процесів соціалізації.

Білоруська держава також віддає перевагу сімейним формам влаштування дітей (виховання дитини в родині в 5-7 разів дешевше, ніж у школі-інтернаті й дитячому будинку). у дитячих будинках сімейного типу натепер виховуються 8 тисяч дітей різного віку. У цих родинах (їх зараз 29) - 200 прийомних дітей, 60 рідних [3, с. 45-56]. $€$ в цій країні і дитяче містечко як один із варіантів дитячого будинку сімейного типу. Воно розташовується в місті Кобрине Брестської області та функціонує за підтримки представників Німеччини. Дитяче містечко складається із триповерхових котеджів, розташованих у мальовничій місцевості, у ньому проживають 12 матерів-виховательок і 120 дітей різного віку - від 1 до 15 років. Дитяче містечко в державі характеризується як відкрита установа, яку можуть відвідувати як фізичні особи, так і представники установ, які фінансують діяльність закладу, а також родичі дітей. На виховання до нього приймаються діти віком до 10 років, проживають по 6-8 дітей у будинках. Діти навчаються в місцевій школі. Дитяче містечко має власний дитячий садок. Діти можуть передаватися на усиновлення чи патронат. Після випуску у 15 років і до остаточного життєвого самовизначення вихованці можуть жити в «дитячому містечку», де передбачена посада наставника-вихователя [1, с. 23-25].

Останніми роками така система широко використовується і в Росії. Так, у селищі Томиліно Московської області в «Дитячому селі SOS" в одинадцяти сім'ях виховуються 56 дітей. Локацію для розташування Комітет освіти Москви виділив безкоштовно, гроші на будівництво було надано благодійними організаціями, приватними особами Росії й інвесторами з-за закордону (зокрема, відомим політиком Габріелою Біттендорф). Вихованці мають хронічні захворювання, порушення психіки, затримки розумового розвитку, а також важкі психічні травми, що пов'язані з періодом перебування в інтернаті або біологічній родині. Виховання здійснюється «прийомними матерями», які виконують функції господині звичайної родини: готовлять їсти, прибирають, займаються пранням, лікують, роблять подарунки і влаштовують свята. Вони мають педагогічну освіту і досвід виховання дітей.

У Санкт-Петербурзі існує притулок «Дом Астрід», де практикується створення домашніх груп, відтворюється досвід роботи притулків у дореволюційній Росії, коли дітей-сиріт віддавали до селянських родин. У газеті «Зміна», урубриці «Візьмименедосебе» друкуютьсяоголошення про цих дітей, з їхніми фотокартками. Підлітки «Дома Астрід» навчаються та займаються господарською діяльністю, яка відповідає їхнім віковим і фізичним особливостям.

У Словаччині та Чехії існують дитячі діагностичні будинки. У них діти перебувають від 1,5 до 2 місяців. За цей період фахівці ставлять медико-психологічний діагноз. Після цього діти направляються в біологічну родину або сімейну форму влаштування, а в разі необхідності - в установу для дітей з особливостями в поведінці [2, с. 43-46].

У В'єтнамі функціонують центри соціального захисту сімейного типу. На утримання однієї дитини в таких установах виділяється 84 тисячі донгів на місяць (6 доларів США). Контингент тих, хто мешкають у цих центрах, розділено на невеликі групи - родини. Кожна родина має матір і складається із 6-8 братів і сестер різного віку. У центрах дітям надається медичне обслуговування, можливість навчатися, здобувати професію, брати участь у заходах відпочинку і дозвілля [1].

Влада Індії звертається до заможних бездітних громадян із Європи і США із проханням взяти у свої сім'ї прийомних дітей із переповнених індійських дитячих будинків. Держава гарантує швидке оформлення необхідної документації щодо влаштування дитини в сім'ю (45 днів). Ця спрощена процедура приваблює іноземців, оскільки в інших країнах ця процедура передбачає більш ретельну перевірку осіб усиновителів та матеріально-побутових умов майбутнього проживання дитини.

У Китаї встановлено досить спірні правила щодо осіб майбутніх батьків: люди, які страждають на ожиріння, старше 50 років, які не перебувають у шлюбі або мають більше двох розлучень, а також мають інші «асоціальні» характеристики, не мають права створювати прийомні сім'ї. Також передані у прийомну сім'ю діти повинні виховуватися в дусі поваги до батьківщини. Прийомним батькам, які не проживають на території держави, пропонують вступати в Асоціацію прийомних батьків китайських дітей із метою виховування дітей в умовах китайської ментальності. Аналогічна позиція могла б знайти відображення і в українському законодавстві.

У багатьох країнах розвинуті превентивні служби, які надають допомогу і батькам, а також дітям у скрутній ситуації. Вилу- 
чення дитини з родини проводиться у крайніх випадках, оскільки вважається, що дитина, позбавлена батьківського піклування і переведена в систему державної опіки, має набагато більше проблем у дорослому житті, ніж дитина, вихована в сім'ї. Отже, аналіз міжнародного досвіду дозволяє стверджувати, що сімейні форми виховання є ефективними і прогресивними щодо реабілітації та соціалізації дітей-сиріт та дітей, позбавлених батьківського піклування [4].

Загальновідомою є педагогічна ідея австрійського вченого і практика Германа Гмайнера, який запровадив життєдіяльність дитячих містечок SOS, де створювалися дитячі будинки за принципом сім'ї.

COC Дитячі Містечка (SOS Kinderdorf International) - це міжнародна незалежна благодійна організація соціального спрямування, яка допомагає дітям у 136 країнах.

Перше COC Дитяче Містечко було засноване в 1949 р. в містечку Імст для дітей-сиріт, батьки яких загинули під час Другої світової війни. Ідея створення СОС Дитячих Містечок базувалася на взаємодії чотирьох складових частин, як-от: 1) мати; 2) брати і сестри; 3) будинок; 4) дитяче містечко.

За час свого життя Герман Гмайнер заснував 230 Дитячих містечок по всьому світі. Ідея створення цих містечок була тричі номінована на Нобелівську премію. Натепер у світі функціонують понад 550 таких містечок.

Отже, удосконалення сімейних форм влаштування дітей-сиріт є міжнародною проблемою. Сучасна міжнародна ситуація характеризується процесами визначення спільних ідей захисту і розвитку дітей, які залишилися без піклування батьків, активно формується наукове і практичне співробітництво в галузі вирішення цих проблем, актуалізуються можливості обміну досвідом та вироблення універсальних рішень. Нині в різних країнах світу створені і діють різні моделі сімейної допомоги та підтримки дітей-сиріт і дітей, позбавлених батьківського піклування. Вище нами вже було диференційовано державно-суспільні форми влаштування дітей-сиріт та дітей, позбавлених батьківського піклування. 3 урахуванням досвіду закордонних країн, уважаємо за доцільне більш детально зупинитися на характеристиці функціонування СОС Дитячих містечок в Україні.

СОС Дитячі Містечка в Україні - недержавна благодійна організація, яка вже понад 17 років в Україні допомагає дітям-сиротам та сім'ям, що опинились у складних життєвих обставинах. Це спеціалізований виховний заклад для проживання, утримання та виховання дітей-сиріт і дітей, позбавлених батьківського піклування, до досягнення ними 18-річного, а в разі продовження навчання в загальноос- вітніх, професійно-технічних, вищих навчальних закладах I-IV рівнів акредитації - 23-річного віку [3].

Місія організації - допомогти кожній дитині рости в люблячій родині.

Основні завдання містечка такі: створення умов для реалізації права дітей на виховання в оточенні, максимально наближеному до сімейного, за принципом родинності, для їхнього фізичного, інтелектуального і духовного розвитку; належне матеріальне забезпечення дітей, сприяння у здобутті ними належної освіти, навичок щодо самостійного життя. Містечко у своїй діяльності керується Конституцією (254к/96-ВР) та законами України, актами Президента України і Кабінету Міністрів України, рішеннями центральних та місцевих органів виконавчої влади, Конвенцією ООН про права дитини (995-021), положенням про містечко. Містечко у своїй діяльності взаємодіє з місцевими органами виконавчої влади, органами місцевого самоврядування, а також підприємствами, установами, організаціями та громадянами.

Головна особливість роботи - комплексний підхід до проблеми сирітства. Організація працює не лише з наслідками, а й над профілактикою, насамперед націлена на збереження родини, налагодження в ній здорової атмосфери. Для цього вразливим сім'ям із дітьми надається як матеріальна (продуктові набори, засобигігієни, ліки), такіфахова нематеріальна підтримка (консультації психологів, педагогів, логопедів, оплата професійних курсів тощо).

Якщо зберегти рідну родину не вдається, організація допомагає забезпечити виховання дитини в безпечному та турботливому сімейному середовищі - прийомної родини, патронатні й опікунські сім'ї, сприяє усиновленню [5].

Організація працює у 5 основних напрямах, яК-От:

1. Робота з родинами у кризі, з дітьми-сиротами, з молодими людьми із числа сиріт та з родин у кризі, з родинами, що постраждали від бойових дій на Сході України, юридична діяльність щодо захисту прав дітей в Україні.

2. Влаштування дітей-сиріт та дітей, які позбавлених батьківське піклування, в альтернативні форми опіки.

3. Підтримка і навчання батьків-вихователів із використанням кращих міжнародних практик.

4. Співпраця 3 державними партнерами в питаннях влаштування дітей і надання послуг прийомним сім'ям.

Вищезазначені напрями роботи об'єднані спільною метою - соціалізацією дитини в родині, запобігання втрати батьківського піклування. Послуги надаються на основі індивідуальної оцінки потреб сімей: від мате- 
ріальної підтримки до тривалої психотерапії й оплати професійних курсів, закупівлі інвентарю для самозайнятості.

Організація працює з молоддю, яка виходить 3-під опіки, та готує її до самостійного життя: функціонує Молодіжний центр, що надає різноманітні послуги (психологічні консультації, освітні заходи, заходи активного відпочинку тощо).

COC Дитячі Містечка в Україні надають допомогу на безкоштовній основі, коштом благодійних внесків. Щорічно організація звітує про цільове використання коштів та проходить зовнішній аудит.

Натепер в Україні працюють такі містечка.

Київ та Київська область. СОС Дитяче Мicтечко Бровари - 14 прийомних родин і дитячих будинків сімейного типу та 2 родини короткотривалого перебування, що разом виховують більше сотні дітей. У кожному сімейному будинку на чолі 3 батьками-вихователями (мама або сімейна пара) живуть 4-9 дітей різного віку і статі. Кожна сім'я живе своїм життям: планує і витрачає сімейний бюджет, вирішує, як проводити дозвілля, куди поїхати, створює свою унікальну атмосферу затишку і комфорту в будинку. Діти відвідують звичайні школи і дитячі сади, поліклініки, здобувають додаткову освіту. У розвитку дітей батькамвихователям допомагають фахівці СОС Дитячого Містечка Бровари. Ведеться планування індивідуального розвитку кожної дитини, де враховуються всі особливості, потреби, можливості дитини. 17 молодих людей проживають за межами СОC Дитячого Містечка Бровари, а 8 - у малому груповому будинку в Києві, що створений організацією у 2018 р. Унікальність даного виду сімейної опіки в нижчезазначеному:

- у підтримці і навчанні батьків-вихователів із використанням кращих міжнародних практик;

- у тісній співпраці з державними партнерами в питаннях влаштування дітей і надання послуг;

- у використанні затверджених державою моделей альтернативного виховання дітей;

- у наданні додаткової підтримки дітям та родинам, як-от житло, оплата комунальних послуг.

Луганська програма відкрита у 2012 р. У співпраці з державними партнерами було створено шість прийомних сімей, інтегрованих у громаду. у 2015-2016 рр. нові родини у Старобільську та Сєвєродонецьку були включені у програму. Нині підтримку отримують 14 сімей, у яких виховується 41 дитина. у 2019 р. було відібрано і навчено перші 5 патронатних сімей у Луганській області [3].
Також сімейні форми виховання здійснюють супровід молоді із числа дітей-сиріт, дітей, які залишилися без батьківського піклування, на етапі дорослішання і переходу до незалежного і самостійного життя.

Підлітки із сімейних форм виховання, які здобули повну загальну середню освіту і продовжують своє навчання в коледжах, вищих навчальних закладах, мають можливість проживати в Малому груповому будинку в місті Києві. Разом з іншими однолітками молоді люди протягом 2-3 років вчаться бути самостійними, брати відповідальність за себе та своє життя.

Соціальні педагоги-наставники Малого групового будинку постійно супроводжують молодь, допомагають у вирішенні нагальних питань і проблем, надають підтримку і отриманні нового соціального досвіду, а також сприяють формуванню емоційної зрілості.

За цей час більше 85000 дітей та дорослих у Київській та Луганській областях отримали підтримку від фонду [3].

Висновки із проведеного дослідження. Отже, сирітство $€$ загальною міжнародною проблемою. Сучасна міжнародна ситуація характеризується пріоритетністю державно-суспільних форм виховання дітей-сиріт і дітей, позбавлених батьківського піклування. Універсальною формою такого виховання нині виступають малі групові будинки. Проблеми, які виникають у процесі ресоціалізації дитини, можуть бути вирішені за умови професійно організованого психологічного супроводу.

\section{ЛІТЕРАТУРА:}

1. Авчухова А.М. Щодо стану подолання та профрілактики соціального сирітства в Україні. Національний інститут стратегічних досліджень. 2010. С. 56-67.

2. COC Дитячі Містечка в Україні. URL: https://sosukraine.org/sos-dityachi-mistechka-v-ukraini/.

3. Флоров Ю.В. История создания «детских деревень» семейного типа. Социальная педагогика. 2004. № 1. C. 14-18.

4. Чечет В.В. Альтернативні форми виховання дітей, які проживають у дитячих установах. Управління освітою. 2003. № 15. С. 10-11.

5. Щербатюк О.В. Зарубіжний досвід роботи альтернативних закладів опіки дітей, позбавлених батьківського піклування. URL: https://www.narodnaosvita. kiev.ua/Narodna_osvita/vupysku/1/statti/5scherbatyuk/5 scherbatyuk.htm.

6. Захист прав дітей $є$ одним із пріоритетів Мінсоцполітики. URL: https://www.msp.gov.ua/news/20075. html?PrintVersion.

7. Скільки дітей в Україні $€$ сиротами : статистика усиновлення. URL: https://24tv.ua/skilki_ditey_v ukrayini_ye_sirotami_statistika_usinovlennya_n̄1160645. 